\title{
METODE DAN STRATEGI PEMBENTUKAN KARAKTER RELIGIUS YANG DITERAPKAN DI SDTQ-T AN NAJAH PONDOK PESANTREN CINDAI ALUS MARTAPURA
}

Oleh:

\author{
Miftahul Jannah \\ Sekolah Tinggi Ilmu Al-Qur'an (STIQ) Amuntai, Kalimantan Selatan
}

\begin{abstract}
Abstrak
Karakter Religius merupakan salah satu aspek kepribadian manusia yang tidak dapat berdiri sendiri, artinya terkait dengan aspek kepribadian dan harus dilatihkan pada anak-anak sedini mungkin agar tidak menghambat tugas-tugas perkembangan anak selanjutnya. kemampuan untuk religius tidak terbentuk dengan sendirinya. Kemampuan ini diperoleh dengan kemauan, dan dorongan dari orang lain termasuk dari seluruh guru, kepala sekolah, pengawas, bahkan komite sekolah harus memberi contoh dan menjadi suri tauladan dalam mempraktekkan indikator-indikator pendidikan karakter dalam perilaku sehari-hari. Sehingga dapat terciptanya pembentukan karakter peserta didik dan seluruh warga sekolah, sehingga pendidikan karakter tidak hanya dijadikan ajang pembelajaran, tetapi menjadi tanggung jawab semua warga sekolah untuk membina dan mengembangkan. Dalam penelitian ini akan melihat Bagaimana metode dan strategi pembentukan karakter religius yang diterapkan di SDTQ-T An Najah Pondok Pesantren Cindai Alus Martapura.

Tujuan dari penelitian ini adalah: Mendeskripsikan dan menganalisis (1)Metode pembentukan karakter religius yang diterapkan di SDTQ-T An Najah Pondok Pesantren Cindai Alus Martapura. (2)Strategi pembentukan karakter religius yang diterapkan di SDTQ-T An Najah Pondok Pesantren Cindai Alus Martapura.

Penelitian ini menggunakan pendekatan kualitatif dengan jenis penelitian studi kasus (study case). Teknik pengumpulan data yang digunakan adalah wawancara, observasi, dan dokumentasi. Data dianalisis seara kualitatif dengan model analisis Miles dan Huberman. Hasil Penelitian menunjukan (1) Metode pembentukan karakter religius yang diterapkan di SDTQ-T An Najah Pondok Pesantren Cindai Alus Martapura. ialah:
\end{abstract}


Miftahul Jannah: Metode dan Strategi Pembentukan Karakter Religius yang Diterapkan di SDTQ-T An Najah Pondok Pesantren Cindai Alus Martapura

menekankan pada metode keteladanan, metode pembiasaan, metode nasehat dan kisah-kisah, metode Metode Tsawâb (Hadiah) dan 'Iqâb (Hukuman) (2) Strategi pembentukan karakter religius yang diterapkan di SDTQ-T An Najah Pondok Pesantren Cindai Alus Martapura Menekankan pada kesadaran, keteladanan/Contoh, Kegiatan spontan, Teguran, Pengkondisian lingkungan, Kegiatan rutin, Disiplin yang terintegrasi

Kata Kunci: Metode, Strategi, Pembentukan Karakter Religius

\section{A. Latar Belakang Masalah}

Karakter Religius merupakan salah satu aspek kepribadian manusia yang tidak dapat berdiri sendiri, artinya terkait dengan aspek kepribadian dan harus dilatihkan pada anak-anak sedini mungkin agar tidak menghambat tugastugas perkembangan anak selanjutnya. kemampuan untuk religius tidak terbentuk dengan sendirinya. Kemampuan ini diperoleh dengan kemauan, dan dorongan dari orang lain.

Pendidikan karakter religius pada sekarang ini dalam kualitas masyarakat mengalami penurunan, seperti terjadinya kekerasan, pornografi, tawuran,dan lainnya. Sehingga dalam pendidikan karakter ini merupakan program pendidikan yang harus diimplementasikan ke dalam pendidikan formal diseluruh jenjang pendidikan nasional. Dengan adanya penerapan pendidikan karakter ini dapat tercapainya tujuan pendidikan nasional untuk menjadikan peserta didik menjadi manusia yang beriman, bertakwa, berakhlak mulia, kreatif cakap dan lainnya

Sekolah adalah pendidikan kedua setelah keluarga, karena secara teratur atau terencana dapat melaksanakan pendidikan dengan baik, dari hal tersebut peserta didik akan mendapat pendidikan, baik dari teman sebaya maupun guru. Dan ketika peserta didik sudah berada di sekolah maka akan lebih focus terhadap pendidikan yang ada di sekolah. ${ }^{1}$

Pendidikan adalah usaha sadar dan terencana untuk mengembangkan potensi peserta didik. Pendidikan formal maupun non formal memiliki strategi

${ }^{1}$ Mohammad Ali, dan Mohammad Asrori, Psikologi Remaja: Perkembangan Peserta Didik, (Jakarta:Bumi Aksara, 2014), h. 42. 
Miftahul Jannah: Metode dan Strategi Pembentukan Karakter Religius yang Diterapkan di SDTQ-T An Najah Pondok Pesantren Cindai Alus Martapura

dalam mencapai tujuandiantaranya pengarahan, pembentukan, dan pembinaan. Pendidikan bukanlah suatu hal yang mudah tetapi juga perlu kebersamaan dalam mencapainya. ${ }^{2}$ Pendidikan perlu adanya karakter, sehinggadapat tercapainya tujuan pendidikan nasional untuk menjadikan peserta didik menjadi manusia yang beriman, bertakwa, berakhlak mulia, kreatif cakap dan lainnya. Karakter merupakan kulminasi dari kebiasaan yang dihasilkan dari pilihan etik, perilaku, dan sikap yang dimiliki individu yang merupakan moral yang prima walaupun ketika tidak seorang pun yang melihatnya. Karakter mencangkup keinginan seseorang untuk melakukan yang terbaik, kepedulian terhadap kesejahteraan orang lain, kognisi dari pemikiran kritis dan pengembangan ketrampilan interpersonal dan emosional yang menyebabkan kemampuan individu untuk bekerja secara efektif dengan orang lain dalam situasi setiap saat. Karakter diharapkan mampu memecahkan berbagai persoalan, khususnya dalam bidang pendidikan, dengan mempersiapkan peserta didik melalui perencanaan, pelaksanaan dan evaluasi terhadap sistem pendidikan, secara efektif, efisien, danberhasil. Karakter memerankan guru sebagai pembentukan karakter dan kompetensi peserta didik, yang harus kreatif dalam memilah dan memilih, serta mengembangkan metode dan materi pembelajaran. Guru harus professional dalam membentuk karakter dan kompetensipeserta didik sesuai dengan karakteristik individual. ${ }^{3}$

Keberhasilan pembentukan karakter dapat diketahui dari berbagai perilaku sehari-hari peserta didik dan warga sekolah lainnya. Perilaku tersebut antara lain diwujudkan dalam bentuk : kesadaran, kejujuran, keikhlasan, kesederhanaan, kemandirian kepedulian, kebebasan dalam bertindak, kecermatan, ketelitian, dan komitmen. ${ }^{4}$ Penerapan karakter religius sangat

\footnotetext{
${ }^{2}$ Maunah, Binti, “Landasan Pendidikan”,(Yogyakartaa: Teras, 2009), h. 179

${ }^{3}$ Wiyani Ardy, Novan, "Bina Karakter Anak Usia Dini: Panduan Orang Tua dan Guru dalam Membentuk Kemandirian dan Kedisiplinan Anak Usia Dini”, (Yogyakarta: Ar-Ruzz Media, 2013), h. 5-6.

${ }^{4}$ Sahlan, Asmaun dan Prasetyo Teguh, Angga, "Desain Pembelajaran BerbasisKarakter", (Yogyakarta: Ar-Ruzz Media, 2012), hal. 134Mulyasa,E, "Guru
} 
Miftahul Jannah: Metode dan Strategi Pembentukan Karakter Religius yang Diterapkan di SDTQ-T An Najah Pondok Pesantren Cindai Alus Martapura

dibutuhkan untuk menghadapi permasalahan-permasalahan yang menghancurkan sistem kemanusiaan, penerapan keagamaan merupakan pembinaan secara keselurhaan dan membutuhkan tenaga, kesabaran, ketelatenan, ruang, waktu dan biaya yang ekstra guna menjadi jembataan dalam Negara sebagai perwujudkan insane kamilyang bertakwa kepada Allah SWT. ${ }^{5}$ Agama memiliki peran sebagai motivasi hidup dan merupakan alat pengembang dan pengendalian diri yang amat penting, tanpa adanya pedoman manusia akan terjerumus kedalam lembah kenistaan dunia dan akhirat. Dapat dilihat hancurnya nilai-nilai yang terlihat oleh jasmani, dunia mulai hancur kefitrahannya.Dimulai dari salah satu alternatif yang dapat dilakukan dalam. pelaksanaan pendidikan karakter di sekolah adalah mengoptimalkan pembelajaran materi pendidikan agama Islam. Peran pendidikan agama khususnya pendidikan agama Islam sangatlah strategis dalam mewujudkan pembentukan karakter peserta didik.

Pendidikan agama merupakan sarana transformasi pengetahuan dalam aspek keagamaan (aspek kognitif), sebagai sarana transformasi norma serta nilai moral yang membentuk sikap (aspek afektif), yang berperan dalam pengendalian prilaku (aspek psikomotorik) sehingga tercipta kepribadian manusia seutuhnya. Pendidikan agama Islam diharapkan mampu menghasilkan manusia yang selalu berupaya menyempurnakan iman, takwa, dan berakhlak mulia mencaakup etika, budi pekerti, atau moral sebagai perwujudan dari pendidikan. Manusia seperti itu diharapkan tangguh dalam menghadapi tantangan, hambatan, dan perubahan yang muncul dalam pergaulan masyarakat baik dalam lingkup lokal, nasional, regional maupun global. Dari ungkapan diatas maka harus menjadi milik seluruh warga sekolah. Maka seluruh guru,

dalam Implementasi Kurikulum 2013”, (Bandung: PT Remaja Rosdakarya, 2016), h. 47.

${ }^{5}$ Amilosa,Putri,"Pembinaan Karakter Religius Santri di Muhammadiyah Boarding School", Jurnal Basic Of Education, Volume 02, No. 02 Januari-Juni, (Ponorogo: Al-Assasiyyah, 2018), hal.15.7Amilosa,Putri,"Pembinaan Karakter Religius Santri di Muhammadiyah Boarding School”, Jurnal Basic Of Education, Volume 02, No. 02 Januari-Juni, (Ponorogo: Al-Assasiyyah, 2018), h. 14-15. 
Miftahul Jannah: Metode dan Strategi Pembentukan Karakter Religius yang Diterapkan di SDTQ-T An Najah Pondok Pesantren Cindai Alus Martapura

kepala sekolah, pengawas, bahkan komite sekolah harus memberi contoh dan menjadi suri tauladan dalam mempraktekkan indikator-indikator pendidikan karakter dalam perilaku sehari-hari. Sehingga dapat terciptanya pembentukan karakter peserta didik dan seluruh warga sekolah, sehingga pendidikan karakter tidak hanya dijadikan ajang pembelajaran, tetapi menjadi tanggung jawab semua warga sekolah untuk membina dan mengembangkan. Dalam penelitian ini akan melihat Bagaimana metode dan strategi pembentukan karakter religius yang diterapkan di SDTQ-T An Najah Pondok Pesantren Cindai Alus Martapura.

\section{B. Metode Penelitian}

\section{Pendekatan dan Jenis Penelitian}

Pendekatan dan Jenis penelitian yang penulis lakukan adalah penelitian kualitatif dengan jenis penelitian studi kasus yang mana penelitan ini bertujuan untuk membahas tentang model dan strategi serta implikasi pembentukan karakter religius yang diterapkan di SDTQ-T An Najah Pondok Pesantren Cindai Alus Martapura.

\section{Data dan Sumber Data Penelitian}

Penelitian ini dikategorikan penelitian kualitatif-empiris, maka data yang digunakan adalah data pokok dan data penunjang. Data pokok adalah data yang penulis dapatkan secara first hand dari informant, sedangkan data sekunder adalah data yang diperoleh dari buku-buku, data dokumentasi, serta karya-karya ilmiah guna mendukung penelitian ini.

\section{Tekhnik Pengumpulan Data}

Ada tiga metode teknik pengumpulan data yang digunakan penulis dalam penelitian ini. Pertama, wawancara dalam melakukan wawancara ini peneliti melakukannya dengan dua tehnik, yaitu wawancara terstruktur dan wawancara tak terstruktur yang dilakukan.. Kedua, observasi yaitu berbaur dengan warga sekolah untuk memahami langsung pendidikan karakter di pondok pesantren dalam pembentukan kedisiplinan, tanggung jawab dan kemandirian siswa yang diteliti. Ketiga, dokumentasi, penulis juga 
Miftahul Jannah: Metode dan Strategi Pembentukan Karakter Religius yang Diterapkan di SDTQ-T An Najah Pondok Pesantren Cindai Alus Martapura

mengumpulkan data dengan cara dokumentasi baik dari buku-buku, arsip dokumen dari sekolah supaya data yang diperoleh lebih akurat dan sistematis.

\section{Tekhnik Analisis Data}

Penulis menganalisis data peneliti menggunakan tehnik analisis data Miles dan Huberman, yang dilakukan melalui tiga langkah: (1) Reduksi data, dengan cara proses pemilihan, pemusatan perhatian, pengabstraksian dan pentransformasian data kasar dari lapangan. Fungsinya untuk menajamkan, menggolongkan, mengarahkan, membuang yang tidak perlu, dan mengorganisasi sehingga interpretasi bisa ditarik kesimpulan. (2) Penyajian data , dengan cara Sekumpulan informasi tersusun yang memberi kemungkinan untuk menarik kesimpulan dan pengambilan tindakan. Bentuk penyajiannya antara lain berupa teks naratif, matriks, grafik, jaringan, dan bagan. (3) Penarikan kesimpulan (verifikasi), dengan cara memeriksa data temuan yang dinilai absah dan kemudian menarik kesimpulan sehingga dapat memperoleh hasil analisis yang sesuai.

\section{Pengecekan Keabsahan Data}

Pengecekan keabsahan data, peneliti menggunakan teknik trianggulasi. Triangulasi adalah teknik pemeriksaan keabsahan data yang memanfaatkan sesuatu yang lain di luar data itu untuk keperluan pengecekan atau sebagai pembanding terhadap data itu. Teknik trianggulasi yang digunakan penulis ada empat, yaitu Triangulasi pengumpulan data, Triangulasi teori, Triangulasi dengan sumber dan Triangulasi metode.

\section{Kerangka Berpikir}

Kerangka berfikir yang digunakan dalam penelitian ini dimulai dari mendiskripsikan pendidikan karakter religius di di SDTQ-T An Najah Pondok Pesantren Cindai Alus Martapura yang didapat dari hasil wawancara, observasi dan dokumentasi. Data temuan penelitian tersebut kemudian dianalisis dengan berbagai macam teori tentang pendidikan karakter, model, strategi pendidikan karakter dalam pembentukan karakter religious. 
Miftahul Jannah: Metode dan Strategi Pembentukan Karakter Religius yang Diterapkan di SDTQ-T An Najah Pondok Pesantren Cindai Alus Martapura

\section{PEMBAHASAN}

\section{Metode Pendidikan Karakter}

Pendidikan karakter merupakan tumpuan perhatian pertama dalam Islam. Hal ini dapat dilihat dari salah satu misi kerasulan Nabi Muhammad SAW, yang utama adalah untuk menyempurnakan akhlak yang mulia. ${ }^{6}$

Berikut diantara Metode-Metode Pendidikan yang digunakan oleh Rasulullah SAW dalam pembentukan akhlak atau karakter:

a. Metode Keteladanan (al-Uswah al- Hasanah)

Secara terminologi, al-uswah berarti orang yang ditiru, bentuk jamaknya adalah usyan. Hasanah berarti baik. Jadi uswah hasanah artinya contoh yang baik, suri teladan. Dalam Al-Quran terdapat ayat yang menjelaskan tentang keteladanan yaitu pada QS. al-Ahzâb/ 33: 21 dan QS. Al-Mumtahanah/ 60: 4. Dalam hal ini yang menjadi teladan adalah sikap dan perilaku Rasulullah SAW.

Metode keteladanan ialah menunjukkan tindakan terpuji bagi peserta didik, dengan harapan agar mau mengikuti tindakan terpuji tersebut. Keteladanan pendidik bagi peserta didik adalah dengan menampilkan alakhlâq al-mahmûdah, yakni seluruh tindakan terpuji, seperti tawadhu', sabar, ikhlas, jujur, dan meninggalkan al-akhlâq al-madzmûmah, akhlak tercela. $^{7}$

b. Metode Pembiasaan (Ta'wîdiyyah)

Secara etimologi, pembiasaan asal katanya adalah biasa. Dalam Kamus Umum Bahasa Indonesia, biasa artinya lazim atau umum; seperti sedia kala; sudah merupakan hal yang tidak terpisahkan dalam kehidupan sehari-hari. ${ }^{8}$ Dengan adanya prefiks "pe" dan sufiks "an" menunjukkan arti

${ }^{6}$ Abuddin Nata, Akhlak Tasawuf (Jakarta: Rajawali Press, 2010), h. 163.

${ }^{7}$ Samsul Nizar dan Zainal Efendi Hasibuan, Hadits Tarbawi: Membangun Kerangka Pendidikan Ideal Perspektif Rasulullah (Jakarta: Kalam Mulia, 2011), h. 7071.

${ }^{8}$ Departemen Pendidikan Nasional, Kamus Besar Bahasa Indonesia (Jakarta: Gramedia Pustaka Utama, 2008), h. 186. 
Miftahul Jannah: Metode dan Strategi Pembentukan Karakter Religius yang Diterapkan di SDTQ-T An Najah Pondok Pesantren Cindai Alus Martapura

proses. Jadi pembiasaan artinya proses membuat sesuatu menjadi biasa, sehingga menjadi kebiasaan. Untuk membentuk peserta didik agar memiliki karakter terpuji, metode ta'wîdiyyah, merupakan metode yang efektif. Dengan metode ta'wîdiyyah ini, peserta didik diharapkan dapat membiasakan dirinya dengan perilaku yang mulia. ${ }^{9}$

Metode pembiasaan adalah metode yang efektif dilakukan oleh seorang guru, karena dapat merubah kebiasaan buruk menjadi kebiasaan baik. Namun, metode ini membutuhkan waktu, tergantung kepada sejauh mana peserta didik terbiasa dengan kebaikan tersebut. Metode inilah yang sering dilakukan Rasulullah SAW dalam membina umat. Misalnya, mendidik sahabat terbiasa salat berjamaah, membiasakan sahabat berpuasa dan perilaku mulia lainnya. ${ }^{10}$

c. Metode Mau'izhah dan Nasehat

Kata mau'izhah berasal dari kata wa'azha, yang artinya memberi pelajaran akhlak/karakter yang terpuji serta memotivasi pelaksanaannya dan menjelaskan akhlak/karakter yang tercela serta memperingatkannya atau meningkatkan kebaikan dengan apa-apa yang melembutkan hati. Adapun nasehat adalah kata yang terdiri dari huruf nun-shad dan $\underline{h} a$ yang ditempatkan untuk dua arti, yakni murni atau tetap, berkumpul dan menambal. Dikatakan, "nashaha asy-syai", maksudnya benda itu asli atau murni, karena orang yang menasehati pada dasarnya sedang memurnikan orang yang dinasehati dari kepalsuan. Jadi nasehat adalah memerintah atau melarang atau menganjurkan yang dibarengi dengan motivasi dan ancaman. Metode nasehat adalah metode yang penting digunakan untuk menggugah perasaan peserta didik. ${ }^{11}$

${ }^{9}$ Samsul Nizar dan Zainal Efendi Hasibuan, Hadits Tarbawi..., h. 73.

${ }^{10} \mathrm{Ibid}$, h.75.

${ }^{11} \mathrm{Ibid}$, h. $75-76$. 
Miftahul Jannah: Metode dan Strategi Pembentukan Karakter Religius yang Diterapkan di SDTQ-T An Najah Pondok Pesantren Cindai Alus Martapura

\section{d. Metode Qashash (Kisah)}

Secara etimologi kata qashash merupakan bentuk jamak dari qisshah, masdar dari qassha yaqusshu. Artinya menceritakan dan menelusuri/mengikuti jejak. Metode kisah mengandung arti suatu cara dalam menyampaikan materi pelajaran, dengan menuturkan secara kronologis, tentang bagaimana terjadinya sesuatu hal, baik yang sebenarnya terjadi ataupun hanya rekaan saja. Metode kisah sangat dianjurkan dalam upaya pembinaan karakter peserta didik. Melalui kisah tersebut peserta didik diharapkan memiliki karakter sesuai dengan akhlak terpuji dan sikap teladan yang terdapat dalam suatu kisah. Allah SWT dalam memberikan pelajaran bagi manusia banyak menggunakan metode kisah, yakni menceritakan kisahkisah yang baik untuk diteladani dan menceritakan kisah-kisah yang buruk untuk ditinggalkan, dan Rasulullah SAW sering menggunakan metode kisah untuk mendidik umat. Jadi, melalui metode kisah diharapkan peserta didik meneladani tokoh yang baik yang terdapat dalam kisah. ${ }^{12}$

e. Metode Amtsâl (perumpamaan)

Metode perumpamaan merupakan salah satu metode pengajaran yang sering digunakan dalam Al-Quran dan hadits Rasulullah SAW, metode ini biasanya digunakan untuk membentuk karakter mulia peserta didik. Metode perumpamaan (amtsâl) merupakan metode yang sering ditemukan dalam hadits Rasulullah SAW. Metode perumpamaan dapat memberikan pemahaman mendalam terhadap hal-hal yang sulit dicerna oleh daya nalar peserta didik, dan meningkatkan tergugahnya perasaan.. ${ }^{13}$

f. Metode Tsawâb (Hadiah) dan 'Iqâb (Hukuman)

Metode Tsawâb (Hadiah) dan 'Iqâb (Hukuman) dalam pandangan Islam/bahasa Arab hadiah diistilahkan dengan tsawâb. Artinya "pahala, upah, dan balasan". Kata ini banyak dikemukakan dalam Al-Quran, khususnya ketika Al-Quran berbicara tentang apa yang akan diterima

\footnotetext{
${ }^{12}$ Ibid, h. 78-79.

${ }^{13} \mathrm{Ibid}$, h. 85-86.
} 
Miftahul Jannah: Metode dan Strategi Pembentukan Karakter Religius yang Diterapkan di SDTQ-T An Najah Pondok Pesantren Cindai Alus Martapura

seseorang berupa balasan baik ketika berada di dunia maupun di akhirat. Tsawâb merupakan penghargaan yang didaptkan oleh seseorang karena suatu perbuatan, sikap, atau tingkah laku positifnya, baik penghargaan yang sifatnya materi maupun non materi.

Sementara 'iqâb atau hukuman adalah suatu bentuk kerugian atau kesakitan yang ditimpakan kepada orang yang berbuat salah. Hukuman adalah suatu cara yang sederhana untuk mencegah terjadinya pelanggaran terhadap peraturan, dengan tujuan agar tidak terulangnya perbuatan itu lagi dan untuk mencegah peserta didik lain tidak menirunya. ${ }^{14}$

Selanjutnya hukuman dalam Islam, termasuk salah satu alat untuk mendidik umat agar selalu melaksanakan syari'at Islam, melaksanakan perintah Allah dan meninggalkan larangan-Nya. Rasulullah SAW juga membolehkan orang tua dan pendidik memukul anak-anak yang berbuat kesalahan, apabila anak yang sudah berusia sepuluh tahun, namun tidak mau melaksanakan shalat.

Metode hadiah dan hukuman adalah metode yang efektif sebagai alat untuk meningkatkan kesadaran dan kehati-hatian peserta didik, agar tetap dalam jalan-Nya. Hanya saja, dalam memberikan kedua metode ini harus memperhatikan teknik dan pendekatan yang tepat. Teknik dan pendekatan yang salah, dapat mengakibatkan kedua metode tersebut tidak memberi manfaat ataupun hasil apa-apa. ${ }^{15}$

\section{Pendidikan Karakter Persfektif Islam}

Pendidikan karakter dalam agam Islam memiliki kesamaan dengan pendidikan akhlak. pengertian akhlak telah banyak dikemukakan oleh para ulama, di antaranya adalah Al-Ghazali dalam kitabnya yang termasyhur "Ihyâ 'Ulûm al-Dîn" mendefinisikan akhlak sebagai: ${ }^{16}$

\footnotetext{
${ }^{14}$ Ibid, h. 86-91.

${ }^{15}$ Samsul Nizar dan Zainal Efendi Hasibuan, Hadits Tarbawi..., h.92-96.

${ }^{16}$ Al-Ghazali, Ihyâ' 'Ulûm ad-Dîn, jilid 3 (t.tp, Syirkah al-Nur Asia, t.th), h.52.
} 
Miftahul Jannah: Metode dan Strategi Pembentukan Karakter Religius yang Diterapkan di SDTQ-T An Najah Pondok Pesantren Cindai Alus Martapura

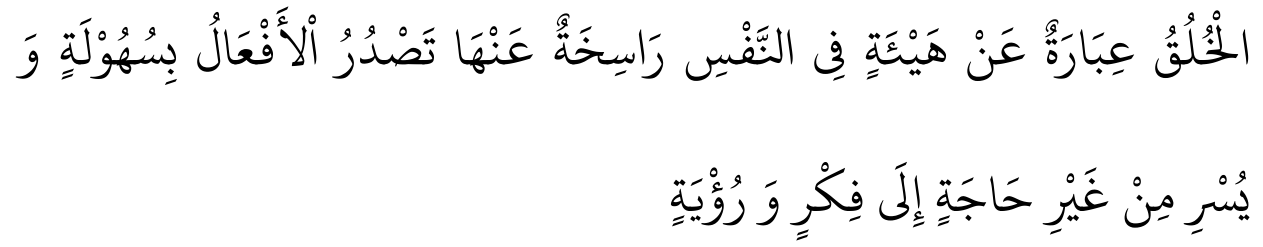

Berdasarkan pengertian ini maka yang dimaksud dengan karakter adalah perbuatan yang terbiasa pada diri seseorang. Ia merupakan refleksi dari perbuatan batinnya dan biasa dilakukan secara berulang-ulang sehingga perbuatannya tanpa memerlukan berbagai pertimbangan akalnya terlebih dahulu. ${ }^{17}$ Ahmad Amin memberikan definisi bahwa akhlak merupakan: ${ }^{18}$

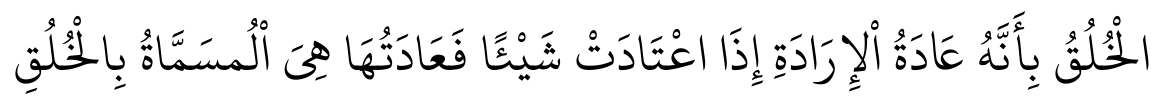

Menyimak pengertian ini, maka yang dimaksud dengan akhlak adalah 'âdatu al-irâdah atau kehendak yang dibiasakan. Dengan kehendak itulah manusia melakukan suatu perbuatan, baik perbuatan batin maupun perbuatan lahir, dan suatu perbuatan yang dibiasakan itulah yang dinamakan akhlak. ${ }^{19}$

Pendekatan Al-Quran dalam menerangkan masalah karakter atau akhlak bukan pendekatan teori saja tetapi dalam bentuk konseptual dan penghayatan. Akhlak yang terpuji dan tercela tergambar dalam perwatakan amnusia. Dalam sejarah dan realita kehidupan manusia semasa Al-Quran diturunkan. Hal ini berseusuaian dengan pribadi Rasulullah sebagai manusia paling sempurna yang menjadi suri tauladan bagi manusia lainnya di berbagai generasi kehidupan. Sesuai dengan Firman Allah dalam surah Al-Ahzab ayat 21, antara lain:

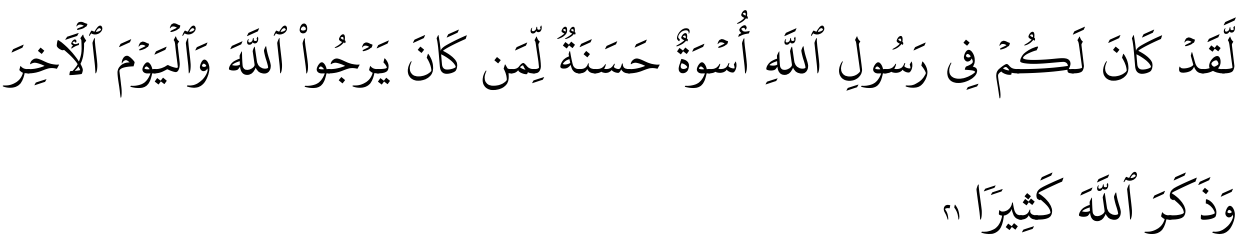

${ }^{17}$ M. Nipan Abdul Halim, Menghias Diri Dengan Akhlak Terpuji (Yogyakarta: Mitra Pustaka, 2000), h. 12.

${ }^{18}$ Ahmad Amin, Etika Ilmu Akhlak (Jakarta: Bulan Bintang, 1995), h. 62.

${ }^{19}$ M. Nipan Abdul Halim, Menghias Diri...,h. 10. 
Miftahul Jannah: Metode dan Strategi Pembentukan Karakter Religius yang Diterapkan di SDTQ-T An Najah Pondok Pesantren Cindai Alus Martapura

Artinya: "Sesungguhnya telah ada pada (diri) Rasulullah itu suri teladan yang baik bagimu (yaitu) bagi orang yang mengharap (rahmat) Allah dan (kedatangan) hari kiamat dan dia banyak menyebut Allah”.(Q.S Al-Ahzab ayat $21)^{20}$

Ayat di atas menunjukkan bahwa Rasulullah sebaik-baiknya suri teladan bagi setiap manusia di muka bumi, tiada kekurangan akhlak atau karakter pada diri beliau, apabila dijadikan teladan bagi kehidupan di bumi ini. Hal ini diperjelas dengan adanya Firman Allah dalam surah Al-Qalam ayat 4, ialah:

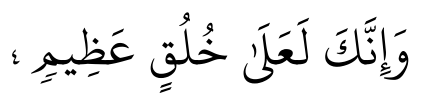

Artinya: "Dan sesungguhnya kamu benar-benar berbudi pekerti yang agung." (Q.S. Al-Qalam ayat 4) ${ }^{21}$

Berdasarkan ayat di atas kita dapat mengetahui bahwa sebaik baik teladan ialah Rasulullah karena beliau memiliki karakter yang paling agung. Karakter dari Rasulullah haruslah kita contoh baik itu contoh perilaku maupun dari tutur kata beliau dikarenakan Rasulullah adalah manusia paling mulia di muka bumi yang nantinya akan memberikan syafaat di hari pertimbangan nanti.

Berikutnya definisi akhlak yang dikemukakan oleh Ibn Maskawaih, menurutnya akhlak merupakan: ${ }^{22}$

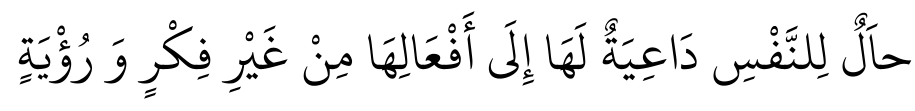

Apabila Ahmad Amin menggunakan istilah irâdah (kehendak), maka Ibn Maskawaih menggunakan hâlu al-nafsi (keadaan jiwa). Di sini dapat diambil garis kesamaan bahwa perbuatan batiniahlah yang mendorong seseorang untuk melakukan perbuatan lahiriah. Meskipun pada hakikatnya

\footnotetext{
${ }^{20}$ Kementrian Agama RI, Al-Quran (Jakarta: Wali, 2013). h. 211.

${ }^{21}$ Kementrian Agama RI, Al-Quran (Jakarta: Wali, 2013). h. 284.

${ }^{22}$ Ibnu Miskawaih, Menuju Kesempurnaan Akhlak, diterjemahkan oleh Helmi Hidayat (Bandung: Mizan, 1994), h. 56.
} 
Miftahul Jannah: Metode dan Strategi Pembentukan Karakter Religius yang Diterapkan di SDTQ-T An Najah Pondok Pesantren Cindai Alus Martapura

kedua perbuatan itu merupakan satu kesatuan perbuatan. Karena perbuatan lahiriah hanyalah merupakan refleksi dari perbuatan batiniah. ${ }^{23}$ Ketika perbuatan ini sudah menjadi kebiasaan dan dilakukan berulang-ulang tanpa memerlukan pemikiran maka yang demikian dinamakan akhlak. Dari ketiga definisi akhlak yang telah dikemukakan para ulama di atas, dapat disimpulkan bahwa akhlak adalah sifat yang tertanam dalam jiwa, dilakukan berulang-ulang dan muncul secara spontan tanpa memerlukan berbagai pemikiran dan perenungan terlebih dahulu. ${ }^{24}$

Akhlak bersifat kejiwaan dan abstrak yang bentuk konkritnya termanifestasikan dalam perbuatan-perbuatan (berupa tindakan atau perilaku). Jika sifat yang tertanam itu darinya terlahir perbuatan-perbuatan baik dan terpuji, maka sifat tersebut dinamakan akhlak yang baik atau terpuji, sebaliknya jika sifat yang tertanam itu darinya terlahir perbuatan-perbuatan jahat dan tercela maka sifat tersebut dinamakan akhlak tercela, dan hal ini sangat tergantung dari cara pembentukan dan pembinaannya Di samping istilah akhlak, juga dikenal istilah etika dan moral. Ketiga istilah itu sama-sama menentukan nilai baik dan buruk sikap dan perbuatan manusia. Perbedaannya terletak pada standar masing-masing. Bagi akhlak standarnya adalah Al-Quran dan Sunnah, bagi etika standarnya pertimbangan akal pikiran, dan bagi moral standarnya adat kebiasaan yang umum berlaku di masyarakat. ${ }^{25}$

\section{Karakter Religius}

Nilai karakter yang terkait erat dengan Tuhan Yang MahaKuasa adalah nilai religius. Kata dasar dari religius adalah religi yangberasal dari bahasa inggris religion sebagai bentuk dari kata benda yang berarti agama atau kepercayaan akan adanya sesuatu kekuatanyang lebih besardi atas manusia. Religius berasal dari kata religiousyang berarti sifat religi yang melekat pada

\footnotetext{
${ }^{23}$ M. Nipan Abdul Halim, Menghias Diri...,h. 11.

${ }^{24}$ Deswita. Akhlak Tasawuf. (Batusangkar: STAIN Batusangkar Press, 2010). h. 13

${ }^{25}$ Yunahar Ilyas, Kuliah...,h. 3.
} 
Miftahul Jannah: Metode dan Strategi Pembentukan Karakter Religius yang Diterapkan di SDTQ-T An Najah Pondok Pesantren Cindai Alus Martapura

diri seseorang. nilai religius merupakan suatu bentuk hubungan manusia dengan penciptanya melalui ajaran agama yang sudah terinternalisasi dalam diri seseorang dan tercermin dalam sikap dan perilakunya sehari-hari. Religius sebagai salah satu nilai dalam pendidikan karakter dideskripsikan oleh Kemendiknas sebagai sikap dan perilaku yang patuh dalam melaksanakan ajaran agama yang dianut, toleran terhadap pelaksanaan ibadah agama lain, dan hidup rukun dengan pemeluk agama lain. Selanjutnya, Ngainum Naim mengungkapkan bahwa nilai religius adalah peghayatan dan implementasi dari ajaran agama dalam kehidupan sehari-hari. Berdasarkan beberapa pendapat dari para ahli dapat disimpulkan bahwa nilai religius merupakan nilai yang bersumber dari ajaran agama yang dianut sesorang yang dilaksanakan dalam kehidupannya sehari-hari.

Akhmad Muhaimin Azzet mengatakan hal yang semestinya dikembangkan dalam diri siswa adalah terbangunnya pikiran, perkataan, dan tindakan siswa yang diupayakan berdasarkan nilai-nilai ketuhanan atau yang bersumber dari ajaran agama yang dianutnya oleh karena itu diharapkan siswa benar-benar memahami dan mengamalkan ajaran dalam kehidupan sehari-hari. Apabila seseorang memiliki karakter yang baik terkait dengan Tuhannya maka seluruh kehidupannya pun akan menjadi lebih baik karena dalam ajaran agama tidak hanya mengajarkan untuk berhubungan baik dengan Tuhan namun juga dalam sesama. ${ }^{26}$ Sayang sekali karakter yang mencerminkan manusia yang beragama tidak selalu terbangun dalam diri setiap orang walaupun dirinya memiliki agama. ${ }^{27}$ Hal ini terjadi karena kurangnya kesadaran dalam keberagamannya. Lebih menyedihkan lagi apabila seseorang beragama hanya sebatas pengakuan saja namun dalam praktek kehidupan sehari-hari sama sekali tidak bersikap, berpandangan, dan berperilaku yang sesuai dengan ajaran agama yang dianutnya.

\footnotetext{
${ }^{26}$ Miskawaih, Ibnu. Menuju Kesempurnaan Akhlak, Diterjemahkan Oleh Helmi Hidayat (Bandung: Mizan, 2011).h. 44

${ }^{27}$ Naim. Ngainun, Character Building. (Jogjakarta: Arus Media, 2012), h. 22
} 
Miftahul Jannah: Metode dan Strategi Pembentukan Karakter Religius yang Diterapkan di SDTQ-T An Najah Pondok Pesantren Cindai Alus Martapura

Nilai-nilai religius harus ditanamkan untuk membentuk karakter bangsa khususnya bagi siswa.Pembentukan karakter harus dimulai dari hal yang terkecil terlebih dahulu yaitu diri sendiri kemudian ditanamkan pada lingkungan keluarga dan akhirnya menyebar ke masyarakat luas. Glok dan Stark dalam Lies Arifah membagi aspek religius dalam lima dimensi sebagai berikut:

a. Religious belief (aspek keyakinan), yaitu adanya keyakinan terhadap Tuhan dan segala sesuatu yang berhubungan dengan dunia gaib serta menerima hal-hal dogmatik dalam ajaran agamanya. Keimanan ini adalah dimensi yang paling mendasar bagi pemeluk agama.

b. Religious practice (aspek peribadatan), yaitu aspek yang berkaitan tingkat keterikatan yang meliputi frekuensi dan intensitas sejumlah perilaku, dimana perilaku tersebut sudah ditetapakan oleh agama seperti tata cara menjalankan ibadah dan aturan agama.

c. Religious felling (aspek penghayatan), yaitu gambaran bentukperasaanyang dirasakan dalam beragama atau seberapa jauh seseorang dapat menghayati pengalaman dalam ritual agama yang dilakukannya misalnya kekhusyukan ketika melakukan sholat.

d. Religious knowledge (aspek pengetahuan), yaitu aspek yang berkaitan dengan pemahaman dan pengetahuan seseorang terhadap ajaran-ajaran agamanya untuk menambahkan pengetahuan tentang agama yang dianutnya.

e. Religious effect (aspek pengamalan), yaitu penerapan tentang apa yang telah diketahuinya dari ajaran-ajaran agama yang dianutnya kemudian diaplikasikan melalui sikap dan perilaku dalam kehidupan sehari-hari.

Selanjutnya, Kementrian Lingkungan Hidup menjelaskan lima aspek religius dalam Islam yaitu:

a. Aspek iman, yaitu menyangkut keyakinan dan hubungan manusia dengan Tuhan, malaikat, para nabi dan sebagainya. 
Miftahul Jannah: Metode dan Strategi Pembentukan Karakter Religius yang Diterapkan di SDTQ-T An Najah Pondok Pesantren Cindai Alus Martapura

b. Aspek Islam, yaitu menyangkut frekuensi dan intensitas pelaksanaan ibadah yang telah ditetapkan, misalnya sholat, puasa dan zakat.

c. Aspek ihsan, yaitu menyangkut pengalaman dan perasaan tentang kehadiran Allah SWT dengan menjalankan perintah-Nya dan menjauhi larangan-Nya.

d. Aspek ilmu, yaitu menyangkut pengetahuan seseorang tentang ajaranajaran agama misalnya dengan mendalami Al-Quran lebih jauh.

e. Aspek amal, menyangkut tingkah laku dalam kehidupan bermasyarakat, misalnya menolong orang lain, membela orang lemah, bekerja dan sebagainya. Dimensi dan aspek dalam nilai religius di atas menjadi acuan untuk menanamkan nilai religius kepada siswa melalui pendidikan karakter. ${ }^{28}$

\section{Strategi Pendidikan Karakter dalam Pembentukan Karakter Religius}

\section{Siswa.}

Strategi juga bisa diartikan sebagai rangkaian keputusan dan tindakan untuk mencapai suatu maksud dalam pencapaian tujuan. Dalam konteks pendidikan strategi adalah seni dan ilmu untuk membawakan pengajaran di kelas sedemikian rupa, sehingga tujuan yang telah ditetapkan dapat tercapai secara efektif dan efisien. Definisi senada strategi adalah cara untuk mencapai tujuan jangka panjang atau proses penentuan rencana para pemimpin puncak.

Strategi Pendidikan dalam Membentuk karakter religius pada siswa atau santri adalah sebagai berikut:

a. Strategi di tingkat kementrian pendidikan dasar

Pendekatan yang digunakan Kementrian Pendidikan Nasional dalam pengembangan Pendidikan Karakter, yaitu: pertama melalui stream top down, kedua melalui stream bottom up, ketiga melalui stream revitalisasi program.

${ }^{28}$ Abdul. Majid. Pendidikan Karakter Perspektif Islam. (Bandung: PT Remaja Rosdakarya, 2011). h. 33 
Miftahul Jannah: Metode dan Strategi Pembentukan Karakter Religius yang Diterapkan di SDTQ-T An Najah Pondok Pesantren Cindai Alus Martapura

1) stream top down

Dalam stream ini pemerintah menggunakan 5 strategi yang dilakukan secara koheran, yaitu sosialisasi, pengembangan regulasi, pengembangan kapasitas, implementasi dan kerjasama, monitoring dan evaluasi.

2) stream bottom up

Dalam stream ini diharapkan dari inisiatif dari satuan pendidikan. Pemerintah memberikan bantuan tekhnis kepada sekolahsekolah yang telah mengembangkan dan melaksanakan pendidikan karakter sesuai dengan ciri khas dilingkungan sekolah tersebut.

3) stream revitalisasi program

Merevitalisasi kembali program-program kegiatan pendidikan karakter dimana pada umumnya banyak terdapat kegiatan ekstrakurikuler yang sudah ada dan setara dengan nilai-nilai karakter.

b. Stategi dalam bentuk Pengintegrasian dalam kegiatan sehari-hari

1) Keteladanan/Contoh

Kegiatan pemberian contoh/teladan dalam hal ini guru mempunyai peran vital dalam proses keteladanan. Sikap dan perilaku guru mempunyai implikasi yang luar biasa terhadap murid-muridnya . kepribadian guru mempunyai pengaruh langsung dan komulatif terhadap perilaku siswa. Perilaku guru dalam mengajar secara langsung atau tidak langsung mempunyai pengaruh terhadap motivasi belajar siswa, baik yang sifatnya positif maupun negatif.

2) Kegiatan spontan

Kegiatan yang dilaksanakan secara spontan pada saat itu juga. Kegiatan ini biasanya dilaksanakan pada saat guru mengetahui sikap/tingkah laku siswa yang kurang baik, seperti meminta sesuatu dengan berteriak atau mencoret dinding. 
Miftahul Jannah: Metode dan Strategi Pembentukan Karakter Religius yang Diterapkan di SDTQ-T An Najah Pondok Pesantren Cindai Alus Martapura

3) Teguran

Guru perlu menegur siswa yang berperilaku buruk dan mengingatkannya agar mengamalkan nilai-nilai baik sehingga dapat membantu siswa mengubah tingkah laku mereka.

4) Pengkondisian lingkungan

Suasana di sekolah dikondisikan sedemikian rupa dengan penyediaan sarana dan prasarana secara baik. Contoh penyediaan tempat sampah, jam dinding, slogan-slogan mengenai karakter kedisiplinan, tanggung jawab, mandiri atau budi pekerti lainnya yang mudah dibaca peserta didik, aturan tata tertib yang ditempelkan pada tempat yang strategis sehingga peserta didik mudah membacanya.

5) Kegiatan rutin

Kegiatan rutin merupakan kegiatan yang dilakukan siswa secara terus-menerus dan konsisten setiap saat. Contoh kegiatan ini adalah berbaris masuk ruang kelas, berdoa sebelum dan sesudah kegiatan, mengucapkan salam bila bertemu dengan orang lain, membersihkan kelas dan belajar.

c. Pengintegrasian dalam kegiatan yang diprogramkan.

Strategi ini dilakukan setelah terlebih dahulu guru membuat perencanaan atas nilai-nilai yang akan diintegrasikan dalam kegiatan tertentu. Hal ini dilakukan jika guru menganggap perlu memberikan pemahaman atau prinsip-prinsip moral yang diperlukan.

d. Melalui manajemen kelas

Praksis pendidikan karakter di dalam kelas menuntut setiap guru untuk memiliki cara-cara untuk bertindak sebagai berikut:

1) Bertindak sebagai pengasuh, teladan dan pembimbing

2) Menciptakans sebuah komunitas moral

3) Menegakkan disiplin moral melalui pelaksanaan kesepakatan yang telah ditentukan sebagai aturan main bersama 
Miftahul Jannah: Metode dan Strategi Pembentukan Karakter Religius yang Diterapkan di SDTQ-T An Najah Pondok Pesantren Cindai Alus Martapura

4) Menciptakan sebuah lingkungan kelas yang demokratis, dengan cara melibatkan para siswa dalam mengambil keputusan atau bertanggung jawab bagi terbentuknya kelas sebagai tempat belajar yang menyenangkan.

5) Mengajarkan nilai-nilai kedispilinan, tanggung jawab dan kemandirian melalui kurikulum dengan cara menggali isi materi pembelajaran dari mata pelajaran yang sangat kaya dengan nilainilai moral.

6) Mempergunakan metode pembelajaran melalui kerja sama agar siswa semakin mampu mengembangkan kemampuan mereka dalam memberikan apresiasi atas pendapat orang lain, berani memiliki pendapat sendiri, dan mao bekerja sama dengan orang lain.

7) Melatih siswa unutk memecahkan konflik yang muncul secara adil dan damai. ${ }^{29}$

e. Strategi Pendidikan dalam Membentuk karakter religius pada siswa atau santri adalah sebagai berikut:

\section{1) Menumbuhkan Konsep Diri (Self Concept)}

Strategi ini menekankan bahwa konsep-konsep diri siswa atau santri merupakan faktor penting dari perilaku, untuk menumbuhkan konsep diri, guru disarankan bersikap empati, menerima hangat, terbuka sehingga siswa atau santri dapat mengeksplorasikan pikiran dan perasannya dalam memecahkan masalah. ${ }^{30}$

2) Memiliki Keterampilan Berkomunikasi

Guru harus memiliki keterampilan komunikasi yang efektif agar mampu menerima semua perasaan, dan mendorong timbulnya kepatuhan peserta didik.

${ }^{29}$ Hendrawan, Saneryo. Spritual Managemen. (Bandung: Mizan, 2009). h. 33

${ }^{30}$ Muchlas Hariyanto. Samani, Konsep dan Model Pendidikan Karakter. (Bandung: PT Remaja Rosdakarya, 2011). h. 23. 
Miftahul Jannah: Metode dan Strategi Pembentukan Karakter Religius yang Diterapkan di SDTQ-T An Najah Pondok Pesantren Cindai Alus Martapura

3) Memberikan Konsekuensi-Konsekuensi Logis dan Alami (Natural And Local Consequences)

Perilaku-perilaku yang salah terjadi karena siswa atau santri telah mengembangkan kepercayaan yang salah terhadap dirinya. Hal ini mendorong munculnya perilaku-perilaku salah. Untuk itu, guru disarankan:

a) Menunjukkan secara tepat tujuan perilaku salah, sehingga membantu peserta didik dalam mengatasi perilakunya.

b) Memanfaatkan sebab-akibat logis dan alami dari perilaku yang salah.

4) Klarifikasi Nilai (Value Clarification)

Strategi ini dilakukan untuk membantu siswa atau santri dalam menjawab pertanyaan sendiri tentang nilai-nilai dan membentuk nilainya sendiri.

5) Analisis Transaksional (Transactional Analysis)

Disarankan agar guru belajar sebagai orang dewasa, terutama apabila berhadapan dengan peserta didik yang menghadapi masalah.

6) Terapi Realitas (Reality Therapy)

Sekolah harus berupaya mengurangi kegagalan dan meningkatkan keterlibatan, dalam hal ini guru harus bersikap positif dan bertanggung jawab.

7) Modifikasi Perilaku (Behavior Modification)

Perilaku salah disebakan oleh lingkungan, sebagai tindakan remediasi. Sehubungan dengan hal tersebut, dalam pembelajaran perlu diciptakan lingkungan yang kondusif.

f. Strategi umum pendidikan karakter yang diterapkan oleh NegaraNegara Barat diantaranya:

\section{1) Cheerleading}

Strategi pemanduan melaui berbagai macam poster-poster atau spanduk, buletin, dan lain sebagainya. 
Miftahul Jannah: Metode dan Strategi Pembentukan Karakter Religius yang Diterapkan di SDTQ-T An Najah Pondok Pesantren Cindai Alus Martapura

\section{2) Praise-and-Reward}

Strategi ini menggunakan pujian dan hadiah yaitu dengan cara memberikan pujian dan sesuatu yang bermanfaat kepada para siswa yang berprestasi bertujuan untuk menjadikan siswa lebih berprestasi lagi.

\section{3) Define-and Drill}

Startegi ini meminta siswa mengingat berbagai hak kebaikan dan mendefinisikannya menggunakan tahaf perkembangan asfek kognitifnya.

\section{4) Forced-Formality}

Strategi ini menggunakan tahap pembiasaan dalam kegiatan sehari-hari dan kebiasaan tersebut dilakukan secara rutin yang bernilai kebaikan moral.

\section{5) Traits Of The Month}

Strategi ini pada umumnya menyerupai strategi cheerleading akan tetapi menggunakan sesuatu yang terkait pendidikan karakter, seperti berbagai pelatihan, kegiatan ekstrakurikuler, sambutan kepala sekolah dan lain sebagainya.

6) Guru Pembimbing

Strategi ini banyak digunakan negara lain. Strategi ini sangat bergantung dari pribadi guru pembimbing karena strategi ini menuntut guru Bimbingan Konseling berperan aktif serta mempunyai sifat sebagai panutan terutama untuk anak didiknya.

\section{Simpulan}

Berdasarkan temuan penelitian dalam uraian dan analisis dalam penelitian ini dapat diambil kesimpulan Metode dan Strategi Pembentukan Karakter Religius yang diterapkan Di SDTQ-T An Najah Pondok Pesantren Cindai Alus Martapura.yaitu: (1) Metode Keteladanan (al-Uswah al-Hasanah)

Metode keteladanan yang ditunjukkan guru adalah dengan tindakan terpuji bagi peserta didik, sehingga anak didik mengikuti tindakan terpuji yang 
Miftahul Jannah: Metode dan Strategi Pembentukan Karakter Religius yang Diterapkan di SDTQ-T An Najah Pondok Pesantren Cindai Alus Martapura

dilakukan oleh guru seperti shalat berjamaah setiap hari mereka lakukan akrena adantya keteladanan yang para guru lakuakn terlebih dahulu dan keteladanan para guru juga terlihat dari sikap para guru dengan menampilkan al-akhlâq almahmûdah, yakni seluruh tindakan terpuji, seperti tawadhu', sabar, ikhlas, jujur,tawakkal dan meninggalkan al-akhlâq al-madzmûmah, akhlak tercela. (2) Metode Pembiasaan (Ta'wîdiyyah) yang dilakukan guru terlihat dari berbagai peraturan yang ada dari anak didik bangun tidur sampai tidur lagi ada peraturan yang mengikat mereka tentunya juga diawasi oleh guru sehingga mereka terbiasa melakukan hal-hal religius, shalat tepat waktu, mengaji setelah shalat magrib dilanjutkan dengan ceramah agama sampai menjelang isya setelah itu shalat isya berjamaah anak-anak belajar pelajaran sekolah dan menghafal ALQuran itu dilakukan mereka setiap hari kecuali malam minggu mereka akan melakukan burdah atau habsyi bersama-sama. (3) Metode Mau'izhah dan Nasehat dan juga metode Qashah (Kisah) juga dilakukan para guru setelah shalat berjamaah selama 5-7 menit para guru menjelaskan akhlak/karakter yang tercela serta memperingatkannya atau meningkatkan kebaikan dengan apa-apa yang melembutkan hati kadang para guru juga membarengi nasehat dengan metode kisah menceritakan perjuangan Rasulullah dan Para sahabat serta perjuangan Ulama-ulama muslim lainnya agar anak-anak mampu menelusuri/mengikuti jejak orang-orang shaleh tersebut yang penuh hikmah dan inspirasi. Metode kisah mengandung arti suatu cara dalam menyampaikan materi pelajaran, dengan menuturkan secara kronologis, tentang bagaimana terjadinya sesuatu hal, baik yang sebenarnya terjadi ataupun hanya rekaan saja. Metode kisah sangat dianjurkan dalam upaya pembinaan karakter peserta didik. (4) Metode Tsawâb (Hadiah) dan 'Iqâb (Hukuman) Metode hadiah dan hukuman adalah metode yang efektif sebagai alat untuk meningkatkan kesadaran dan kehati-hatian peserta didik, agar tetap dalam jalan-Nya.

Strategi pendidikan karakter religius siswa di SDTQ-T An Najah Pondok Pesantren Cindai Alus Martapura ialah: (1) Menekankan pada kesadaran (al-wa'yu al-nafsi) akan pentingnya hidup religius dalam kehiduan 
Miftahul Jannah: Metode dan Strategi Pembentukan Karakter Religius yang Diterapkan di SDTQ-T An Najah Pondok Pesantren Cindai Alus Martapura

sehari-hari, Apabila seseorang memiliki karakter yang baik terkait dengan Tuhannya maka seluruh kehidupannya pun akan menjadi lebih baik karena dalam ajaran agama tidak hanya mengajarkan untuk berhubungan baik dengan Tuhan namun juga dalam sesama. (2) Melakukan teguran secara spontan dan juga keteladanan secara langsung kepada siswa, (3) Keteladanan/Contoh, (4) Kegiatan spontan, ialah Kegiatan yang dilaksanakan secara spontan pada saat itu juga, (5) Teguran, (6) Pengkondisian lingkungan, (7) Kegiatan rutin, (8) Disiplin yang terintegrasi (assertive disipline) ialah mengembangkan dan mempertahankan peraturan dan aktivitas-aktivitas religius seperti dalam konsep pengamalam Para siswa semakin rajin dan giat dalam melakukan kegiatankegiatan religius seperti pada saat waktu Dhuha mereka akan segera mengambil air wudhu dan melaksanakannya tanpa disuruh lagi, ketika waktu Zhuhur mereka semua berwudu dengan tertib dan memasuki mushala tanpa ribut atau gaduh, dilanjutkn zikir mengahfal Al-Quran 1 jam setelah masuk itu memasuki kelas masing-masing untuk mealnjutkan pelajaran sekolah sampai pukul 13.30 wit mereka pulang ke asrama tidur siang dan bangun pukul 15.00 wita untuk mandi, murajaah dan bersiap-siap shalat Ashar berjamaah di mushala. 
Miftahul Jannah: Metode dan Strategi Pembentukan Karakter Religius yang Diterapkan di SDTQ-T An Najah Pondok Pesantren Cindai Alus Martapura

\section{Daftar Pustaka}

Amin, Ahmad. Etika ilmu akhlak. Jakarta: Bulan Bintang, 2010.

Azra, Azyumardi. Pendidikan Islam: Tradisi dan Modernisasi di Tengah Tantangan Milenium. Jakarta: Kencana Prenada Media Group, 2012.

Basrowi dan Suwandi. Memahami Penelitian Kualitatif. Jakarta: Rineka Cipta, 2008.

Bungin, Burhan. Metodologi Penelitian Kualitatif. Jakarta: Raja Grafindo Persada, 2011.

Departemen Agama RI. Pola Pengembangan Pondok Pesantren. Jakarta: Direktorat Jenderal Kelembagan Agama Islam/ Direktorat Pendidikan Keagamaan Islam dan Pondok Pesantren, 2003.

Djakfar, Muhammad. Agama, Etika dan Ekonomi Malang: UIN Maliki Press, 2014.

Durkheim, Emile. Pendidikan Moral: Suatu Studi Teori dan Aplikasi Sosiologi Pendidikan. Jakarta: Erlangga, 1990.

Gunawan, Heri. Pendidikan Karakter: Konsep dan Implementasi. Bandung: Alfabeta, 2012.

Halim. Menghias Diri Dengan Akhlak Terpuji. Yogyakarta: Mitra Pustaka, 2008.

Hendrawan, Saneryo. Spritual Managemen. Bandung: Mizan, 2009.

Hurlock, Elizabeth B. Perkembangan Anak, Diterjemahkan Oleh Med. Meitasari Tjandrasa. Jakarta: Penerbit Erlangga, T. Th.

Indonesia, Republik. Undang-Undang SISDIKNAS. Bandung: Fokusmedia, 2010.

Jamal, Abdurrahman. Cara Nabi Menyiapkan Generasi. Surabaya: CV Fitrah Mandiri Sejahtera, 2006.

J. Moleong, Lexi. Metode Penelitian Kualitatif. Bandung: PT. Remaja Rosdakarya, 2006. 
Miftahul Jannah: Metode dan Strategi Pembentukan Karakter Religius yang Diterapkan di SDTQ-T An Najah Pondok Pesantren Cindai Alus Martapura

Kesuma, Darma. Pendidikan Karakter Kajian Teori dan Praktek Di Sekolah. Bandung: PT Remaja Rosdakarya, 2011.

Khan,Yahya. Pendidikan Karakter Berbasis Potensi Diri. Yogyakarta: Pelangi Publishin, 2010.

Majid, Abdul. Pendidikan Karakter Perspektif Islam. Bandung: PT Remaja Rosdakarya, 2011.

Maksudin. Sistem Pendidikan Asrama School Efektif Untuk Pendidikan Karakter Building. Yogyakarta: Prenada Press, 2010.

Masyhud M. Sulthon dan Moh. Khusnurdil. Manajemen Pondok Pesantren. Jakarta:Diva Pustaka, 2006.

Miskawaih, Ibnu. Menuju Kesempurnaan Akhlak, Diterjemahkan Oleh Helmi Hidayat Bandung: Mizan, 2011.

Muchlish, Masnur. Pendidikan Karakter Menjawab Tantangan Krisis Multidemensional. Jakarta: Bumi Aksara. 2011.

Mufarokah, Anissatul. Strategi dan Model-Model Pembinaan. STAIN Tulungagung: Press, 2008.

Mulyasa, E. Manajemen Pendidikan Karakter. Jakarta: PT Bumi Aksara, 2011.

Mujamil, Qomar. Pesantren: Dari Transformasi Metodologi Menuju Demokratisasi Institusi. Jakarta: Erlangga, 2010.

Ngainun, Naim. Character Building. Jogjakarta: Arus Media, 2012.

Qomar, Mujamil. Pesantren: Dari Transformasi Metodologi Menuju Demokratisasi Institusi, Jakarta: Erlangga. 2012.

Rahardjo, Pendidikan Karakter Sebagai Upaya Menciptakan Akhlak Mulia dalam Jurnal Pendidikan dan Kebudayaan (Jakarta: Balitbang Kemendiknas, Vol 16 Edisi Khusus Iii, Oktober 2010

Razak, Nasruddin. Dienul Islam. Bandung: PT Al-Ma'arif, 1971.

Samani, Muchlas Hariyanto. Konsep dan Model Pendidikan Karakter. Bandung: PT Remaja Rosdakarya, 2011.

Syarifuddin, Ahmad. Mendidik Anak Membaca, Menulis dan Mencintai AlQuran. Jakarta: Gema Insani, 2004. 
Miftahul Jannah: Metode dan Strategi Pembentukan Karakter Religius yang Diterapkan di SDTQ-T An Najah Pondok Pesantren Cindai Alus Martapura

Tu'u, Tulus. Peran Disiplin Pada Perilaku dan Prestasi Siswa. Jakarta: Gramedia Widia Sarana Indonesia, 2004.

Wajdi, Farid. Quantum Tahfiz. Palembang: Ykm Press, 2010.

Wibowo, Agus. Pendidikan Karakter, Strategi Membangun Karakter Bangsa. Yogyakarta: Pustaka Pelajar, 2012.

Wirawan, Model Pendidikan Karakter melalui kegiatan Belajar Mengajar di SMA Islam Terpadu Martapura. Tesis. UIN Antasari Banjarmasin. 2013.

Yasin, A. Fatah. Dimensi-Dimensi Pendidikan Islam. Yogyakarta: Sukses Offset, 2008.

Yaqin, Husnul. Sistem Pendidikan Pesantren di Kalimantan Selatan, Banjarmasin: Antasari Press, 2010. 